\title{
ПРОБЛЕМА РОЗВИТКУ ДІАГНОСТИЧНОЇ КОМПЕТЕНТНОСТІ ВИКЛАДАЧІВ ВИЩОЇ ВІЙСЬКОВОЇ ШКОЛИ В ПЕДАГОГІЧНІЙ ТЕОРІї ТА ПРАКТИЦІ
}

У статті авторкапроаналізувалатеоретичні та практичні аспектирозвитку діагностичної компетентності викладачів іноземних мов ВВНЗ. Проаналізовано та диферениійовіано сутність ключових понять компетентнісного підходу: "компетентність» та «професійна компетентність викладача ВВНЗ.

Ключові слова:компетентнісний підхід, професійна компетентність викладача ВВНЗ,іншомовна комунікативна компетентність, педагогічна діагностика.

Постановлення проблеми в загальному вигляді. Інтеграція України в європейський освітній простір визначає важливим аспектом державної освітньої політики впровадження компетентнісного підходу (КП) до підготовки фахівців у закладах вищої освіти. Тому результатом сучасної освіти $\epsilon$ сформованість різного набору компетентностей, які слугують підгрунтям для успішної професійної діяльності майбутніх спеціалістів. Іншою тенденцією сьогодення $є$ слідування підходу до навчання впродовж усього життя, яке передбачає безперервне навчання, що націлене на розвиток спроможності та бажання дорослих постійно самовдосконалюватися.

Сьогодні, відповідно до концепції КП, викладачі іноземних мов (IM)вищих військових навчальних закладів (ВВН3)мають бути сфокусованими на безперервному розвитку своєї професійної компетентності для того, щоби відповідати цілям мовної політики Збройних Сил України, яка ставить акцент як на розвитку іншомовної комунікативної компетентності (ІКК) офіцерів(курсантів, слухачів), так і на розвитку діагностичної компетентності викладачів вищої військової школи, оскільки всебічна підготовка всіх суб'єктів освітнього процесу сприятиме ефективному впровадженню стандартів НАТО у військово-професійну діяльність офіцерів.

Відповідно до «Основних засад мовної підготовки особового складу в системі Міністерства оборони України» викладачі IM ВBНЗ повинні зосереджуватися на розвитку всіх компонентів ІКК слухачів (курсантів)та супроводжувати цей процес діагностичною діяльністю, яка має на меті визначення оптимальних шляхів i засобів підвищення якості іншомовної підготовки військовослужбовців. Тому одним з основних завдань сьогодення $\epsilon$ питання розвитку діагностичної компетентності викладачів IM ВВНЗ[13].

Аналіз останніх досліджень i публікацій. Проблема впровадження компетентнісного підходу знайшла своє відображення в працях I. Беха, 
А. Вітченка, М. Голованя, І. Драч, О. Дубасенюк, І. Зязюна, О. Овчарук, С. Сисоєвої та В. Ягупова. Науковці вважають, що КП зміщує акценти із традиційного знаннєвого підходу, що зосереджується на нагромадженні знань, умінь та навичок, на формування й розвиток у майбутніх фахівців здатності та готовності практично діяти і творчо застосовувати набуті знання й досвід у різних професійних ситуаціях.

Питання розвитку професійної компетентності викладачів віднайшло відображення в дослідженнях науковців І. Зязюна, С. Гончаренка, С. Демченка, О. Дубасенюк, І. Зимньої, А. Макарової, Н. Ничкало, О. Пометун, В. Свистун, В. Ягупова та ін. Науковці сходяться на думці, що професійна компетентність викладача $є$ складним та комплексним утворенням і передбачає їхню здатність та готовність виконувати професійні обов'язки, що грунтуються на наукових знаннях та професійному досвіді.

Особливості та функції педагогічної діагностики висвітлено в працях В. Аванесова, Б. Бітінаса, I. Булаха, А. Вітченка, Г. Гаца, В. Галузяка, Л. Давидова, К. Інгенкампа, I. Лернера, Є. Михайличева, І. Підласого, Т. Плохути, О. Рибчука,В. Ортинського, В. Ягупова та ін. Теоретичним підгрунтям для розвитку діагностичної компетентності викладачів IM BBHЗ $\epsilon$ результати наукових досліджень К. Барс, С. Брудера, Г. Гаца,М. Геннінгера, О. Дорофеєвої, О. Застело, А. Келава, Ю. Клюг, В. Крикун, С. Мартиненко, Н. МкЕлвані, А. Оле, В. Осьодла, К. Спіел, Б. Шмітца та ін.

Аналізуючи наукову літературу, присвячену питанням розвитку компетентностей фахівців різних галузей, ми дійшли висновку, що особливості розвитку діагностичної компетентності викладачів іноземних мов вищої військової школи було недостатньо висвітлено вченими.

Мета статті полягає в теоретичному аналізі проблеми розвитку діагностичної компетентності викладачів іноземних мов вищих військових навчальних закладів. У межах дослідження нами визначені такі завдання: 1) проаналізувати сутність ключових понять компетентнісного підходу: «компетентність» та «професійна компетентність викладача вищого військового навчального закладу»; 2) дослідили теорію і практику розвитку діагностичної компетентності викладачів IM ВВНЗ.

Виклад основного матеріалу. У системі вищої військової освіти методологічним підгрунтям професійної підготовки викладачів та військових фахівців освіти науковці розглядають КП, відповідно до якого особистість на основі наявних знань, умінь, навичок, ставлень, власного досвіду, цінностей $\epsilon$ здатною та готовою ефективно виконувати свої професійні обов'язки, адаптуючись до мінливості ситуацій, які виникають, і водночас постійно бути спрямованою на самовдосконалення. КП оперує поняттям «компетентність», яке кожен дослідник тлумачить 3 урахуванням специфіки сфери своєї професійної діяльності та предмету дослідження(табл. 1.). 


\section{Підходи науковців до визначення поняття«компетентність»}

\begin{tabular}{|c|c|}
\hline Дослідники & Визначення поняття «компетентність» \\
\hline О. Дубасенюк & $\begin{array}{l}\text { «Системно-структурне багаторівневе інтегральне особистісно- } \\
\text { діяльнісне утворення, яке дозволяє фахівцю ставити й ефективно } \\
\text { вирішувати професійні задачі та проблеми різного рівня складності в } \\
\text { типових та нестандартних ситуаціях»[9]. }\end{array}$ \\
\hline О. Діденко & $\begin{array}{l}\text { «Інтегрована особистісно-діяльнісна категорія, яка формується під } \\
\text { час навчання в результаті поєднання початкового особистого досвіду, } \\
\text { знань, способів діяльності, вмінь, навичок, особистісних цінностей та } \\
\text { здатності їх застосування в процесі продуктивної діяльності стосовно } \\
\text { кола предметів та процесів певної галузі людської діяльності»[6]. }\end{array}$ \\
\hline I. Драч & $\begin{array}{l}\text { «Інтегративна особистісно-професійно системна характеристика } \\
\text { якостей людини, яка забезпечує їі успішну діяльність у професійній та } \\
\text { соціальній сферах, сприяє саморозвитку і самовдосконаленню в } \\
\text { умовах постійних змін»[8]. }\end{array}$ \\
\hline М. Головань & $\begin{array}{l}\text { «Інтегративне утворення особистості, що поєднує в собі знання, } \\
\text { уміння, навички, досвід i особистісні якості, які обумовлюють } \\
\text { прагнення, готовність і здатність розв’язувати проблеми і завдання, } \\
\text { що виникають в реальних життєвих ситуаціях, усвідомлюючи при } \\
\text { цьому значущість предмету і результату діяльності»[5]. }\end{array}$ \\
\hline $\begin{array}{l}\text { В. Свистун, } \\
\text { В. Ягупов }\end{array}$ & $\begin{array}{l}\text { «Підготовленість (теоретична, практична, особистісна, психологічна } \\
\text { тощо) до здійснення певної професійної діяльності та наявність } \\
\begin{array}{l}\text { професійно важливих якостей фахівця, які сприяють цій } \\
\text { діяльності»[15]. }\end{array}\end{array}$ \\
\hline I. Зязюн & $\begin{array}{l}\text { «Властивість індивіда, існує в різних формах - як високий рівень } \\
\text { умілості, як спосіб особистісної самореалізації (звичка, спосіб } \\
\text { життєдіяльності, захоплення); як деякий підсумок саморозвитку } \\
\text { індивіда, форма вияву здібностей і ін.»[10]. }\end{array}$ \\
\hline О. Пометун & $\begin{array}{l}\text { «Спеціально структуровані набори знань, умінь, навичок і ставлень, } \\
\text { яких набувають у процесі навчання» [12]. }\end{array}$ \\
\hline Дж. Равен & $\begin{array}{l}\text { «Специфічна здатність особи, необхідна для ефективного виконання } \\
\text { конкретної діяльності в певній предметній галузі, яка включає як } \\
\text { вузькоспеціальні знання, особливого роду предметні навички, способи } \\
\text { мислення, а також розуміння відповідальності за свої дії»[14]. }\end{array}$ \\
\hline $\begin{array}{l}\text { C. Моншатр } \\
\text { (S. Monchatre) }\end{array}$ & $\begin{array}{l}\text { «Сукупність здатностей, що дозволяє фахівцю належним чином } \\
\text { виконувати завдання за призначенням у життєвих ситуацій на роботі і } \\
\text { відповідати вимогам, які до нього висуваються»[21]. }\end{array}$ \\
\hline $\begin{array}{l}\text { К. Шовіне } \\
\text { (С. Chauvigné) та } \\
\text { Ж.-К. Kyле } \\
\text { (J.-C. Coulet) }\end{array}$ & $\begin{array}{l}\text { «Динамічне поєднання когнітивних та метакогнітивних навичок, } \\
\text { знань, а також усвідомлення міжособистісних, інтелектуальних та } \\
\text { практичних навички та етичні цінності»[18]. }\end{array}$ \\
\hline
\end{tabular}

Цікавим поняттям для проведеного дослідження $\epsilon$ «професійна компетентність викладача ВВНЗ», яке в науковій літературі розглядається як особистісне новоутворення, інтегральний показник готовності до вирішення 
освітніх завдань на основі здобутих під час навчання знань, умінь, навичок, сформованої культури педагогічного спілкування, етики й естетики педагогічної діяльності в умовах ВВНЗ[2].Учені поділяють професійну компетентність викладача ВВНЗ на такі часткові компетентності[2]:

теоретико-методологічну(сформованість цілісного уявлення про філософські й загальнонаукові засади вищої військово-професійної освіти, іiі мету й завдання, пріоритети й цінності; здатність обгрунтовано, переконливо з'ясовувати роль науки в системі формування особистості військовослужбовця);

предметно-діяльнісну (здатність використовувати набуті фахові, психолого-педагогічні знання, вміння для ефективного вирішення освітніх завдань);

інформаційно-комунікативну (здатність застосовувати різноманітні джерела та способи отримання інформації для виконання освітніх завдань, готовність за їхньою допомогою постійно поглиблювати власні знання; сформованість культури педагогічного спілкування, володіння різноманітними засобами, прийомами і формами комунікації);

діагностично-прогностичну (здатність діагностувати рівень підготовки курсантів і слухачів, передбачати результати власної педагогічної діяльності);

управлінську (здатність, пов'язана із самоорганізацією та управлінським забезпеченням навчального процесу -плануванням, організацією, контролем);

проєктувально-корекційну (здатність проєктуватий коригувати власну професійну діяльність, постійно працювати над іï вдосконаленням);

технологічну (володіння технологіями та методиками викладання, здатність добирати методи й засоби з урахуванням освітніх завдань, рівнів підготовки курсантів і слухачів, перспектив їхнього професійного зростання);

науково-дослідницьку (здатність самостійно проводити теоретичні та прикладні дослідження, використовувати їхні результати в навчальному процесі; готовність керувати науково-дослідницькою діяльністю курсантів і слухачів);

етичну (дотримання педагогічної етики в професійній діяльності, спілкуванні, міжособистісних стосунках тощо);

загальнокультурну (повага до національної i світової культурної спадщини; здатність естетизувати власну діяльність, виявляти толерантність, тактовність, ввічливість у спілкуванні з колегами тощо);

творчу (здатність до творчої діяльності в іiі різновидах і формах, готовність генерувати нові педагогічні ідеї та реалізовувати їх на практиці).

У контексті наукових розвідок, присвячених дослідженню розвитку професійної компетентності викладачів IM BBНЗ, вважаємо за потрібне зазначити, що iï сутність полягає в здатності та готовності викладачів реалізовувати свої педагогічні функції в певних ситуаціях [22];науковці виділяють такі компоненти професійної компетентності викладачів IM ВBН3: комунікативний, філологічний, психолого-педагогічний, соціальний, методичний, компенсаторний, загальнокультурний, діагностичний, а також 
педагогічне й мовне мислення, включно методологічне, тактичне й оперативне мислення, особистісні якості- моральні, етичні, ділові [1; 22].

Питанням формування та розвитку діагностичної компетентності фахівців займалися як українські вчені: Г.Гац (формування діагностичної компетентності майбутніх учителів фізичної культури), О. Застело (розвиток діагностичної компетентності викладачів IM ВBН3),С. Мартиненко (формування діагностичних компетентностей у майбутніх учителів початкової школи), так і іноземні вчені: К. Барс та М. Хенінгер (розвиток діагностичної компетентності викладачів засобами мультимедійних технологій навчання),О. Дорофеєва (формування діагностичної компетентності викладачів у процесі додаткової професійної освіти), Ю. Клюг, С. Брюдер, А. Келава, К. Спіел, БШмітс (розвиток діагностичної компетентності викладачів із застосуванням технологій ситуативного аналізу для діагностування навчальної поведінки (стратегій навчання) студентів).

У своїх наукових розвідках вчені виділяють такі важливі характеристики, які $\epsilon$ основою для розуміння сутності «діагностичної компетентності викладача», зокрема це його здатність і готовність (теоретична і практична) до:

здійснення діагностичної діяльності для вирішення професійних проблем та завдань, які виникають під час професійної педагогічної діяльності;

використання сучасних методів, методик, технологій та засобів педагогічного діагностування та дотримування педагогічних принципів;

проведення дослідження та прогнозування розвитку освітнього процесу загалом і конкретного студента зокрема на основі знань про педагогічну діагностику, сформованих діагностичних умінь, навичок, досвіду;

професійного виявлення проблем та прогалину знаннях та причин їхнього виникнення, обгрунтованого вибору навчального змісту та методів навчання;

адаптації свого стилю викладання до потреб студентів із різними здібностями до навчання, їхніх інтересів та вподобань, що передбачає накопичення діагностичної інформації i, 3 огляду на це, підбір методів викладання для всіх студентів $[4 ; 7 ; 11 ; 16 ; 17 ; 20 ; 21]$.

Слушно зауважують іноземні вчені, що діагностична компетентність викладачів передбачає наявність у них таких професійно важливих якостей, як мотивація, цілеспрямованість особистісне ставлення до своєї діяльності, ввічливість, тактовність тощо [19; 23].

Теоретичний аналіз наукових праць, у яких розглядалися питання формування та розвитку діагностичної компетентності викладачів IM ВВН3, дає змогу стверджувати, що ця компетентність передбачає наявність у них діагностичних знань про сутність та зміст педагогічної діагностики, методи отримання інформації, критерії їхньої якості та шляхи уникнення недоліків, правила обробки результатів та їхнє порівняння з наявними нормами, можливі діагностичні висновки. Викладачі іноземних мов мають також володіти методологічними уміннями щодо визначення цілей, завдань діагностичних заходів, а також їхнього планування. Не менш важливим для викладачів IM ВВНЗ є технічні уміння, що передбачають застосування для збору інформації сучасних методик, самостійне створення діагностичних методик та 
інструментів, обробку отриманої інформації, контроль та оцінювання. А для того щоби ефективно і професійно визначати та витлумачувати діагностичну інформацію для правильного постановлення педагогічного діагнозу викладачі IM ВBНЗ повинні демонструвати інтелектуально-діагностичні вміння.

Аналіз наукових розвідок порушеного питання показав, що діагностична компетентність викладачів IM BBH3 є складним утворенням, яку науковці здебільшого розкривають через здатність та готовність до здійснення педагогічної діагностики або діагностичного супроводу. Нами визначено діагностичну компетентність викладача IM ВBН3 як інтегративну особистіснопсихологічну здатність та професійно-діяльнісну готовність до здійснення педагогічної діагностики, діагностичного супроводу, системного збору даних щодо рівня володіння ІКК офіцерів, прийняття рішення та планування заходів щодо підвищення рівня ІКК на основі застосування в професійній діяльності діагностичних знань, методологічних, технічних та інтелектуальнодіагностичних умінь.

Звідси випливає, що діагностична компетентність викладачів IM ВBН3 передбачає здійснення відповідного втручання у процес навчання в режимі реального часу, особливо на початкових етапах із метою забезпечення відповідності мовної підготовки потребам певних слухачів (курсантів), що досягається завдяки процесу діагностування. Діагностичні навички можуть бути використані як основа для обгрунтованого осмислення навчальних процесів студентів, а діагностичні дані - слугувати основою для оцінювання ефективності навчання та планування майбутніх дій на ключових етапах навчального процесу. Окрім цього, викладачі IM BBHЗ у межах своєї діагностичної компетентності мають бути готовими створювати навчальне середовище, а також виявляти та усувати потенційні джерела помилок, які допускають слухачі (курсанти) під час вивчення іноземних мов. Усі суб'єкти навчання можуть використовувати діагностичну інформацію як зворотний зв'язок для того аби змінити стратегію навчання та викладання.

У контексті нашого дослідженнями дійшли висновку, що діагностична компетентність викладачів IM ВBНЗ не зводиться лише до точності суджень діагностики та результатів проведення стандартизованих тестувань, а й передбачає діагностування їхніх стратегій навчання.

Науковці наголошують на важливості розвитку діагностичної компетентності викладачів у навчальному процесі і пропонують реалізувати такі шляхи іiі оптимізації:

інтеграцію модульних курсів із відповідним рівнем розвитку діагностичних та комунікативних навичок 3 англійської мови в процес професійної підготовки викладачів, що дає змогу викладачам підвищити свій рівень професійної компетентності [20];

розроблення методик з урахуванням комплексу знань, якими має володіти фахівець, систему практичних вмінь та навичок, які лежать в основі діагностичної діяльності, досвід у галузі діагностичної діяльності [4]; 
використання викладачами ІМ ВВНЗ спеціальної технології інтегрального оцінювання розвиненості ІКК, спеціалізованих програмних забезпечень як основи розвитку їхньої діагностичної компетентності [22];

моделювання розвитку діагностичної компетентності викладачів iз застосуванням технологій ситуативного аналізу для діагностування навчальної поведінки (стратегій навчання) студентів [19];

застосування мультимедійних технологій навчання (мультимедійного навчального середовища), які завдяки платформам електронного навчання, інтернет-ресурсам для навчання та комп'ютерного чи веб навчання сприяють набуттю спеціальних знань [17].

Отже, аналіз наукових розвідок порушеного питання показав, що діагностична компетентність викладачів IM ВBНЗ є складним утворенням, яку науковці розкривають через здатність та готовність до здійснення педагогічної діагностики або діагностичного супроводу. Педагогічна діагностика, як одна 3 основних функцій викладача IM ВBН3, має розглядатися як цілеспрямований та керований процес вивчення сукупності об'єктивних і суб'єктивних чинників організації іншомовної підготовки військових фахівців у ВВНЗ із метою 3'ясування наявності належних умов та їхньої особистісної здатності до оволодіння іноземною мовою й розвитку іншомовної комунікативної компетентності, а також готовності до виконання завдань за призначенням в іншомовному військово-професійному середовищі та під час проведення спільних бойових дій (операцій) з підрозділами НАТО. Педагогічна діагностика відіграє ключову роль у професійній діяльності викладача IM ВBН3. Успішність реалізації педагогічної діагностики, а також практичне застосування сучасних методик вимагає від викладача IM ВBНЗ сформованості належної діагностичної компетентності.

\section{ВИСНОВКИ}

Здійснений теоретичний аналіз проблеми розвитку діагностичної компетентності викладачів іноземних мов вищих військових навчальних закладів засвідчує, що ця проблема $є$ актуальною і дає підстави для таких висновків:

1. За належного рівня розвитку діагностичної компетентності викладачів IM ВВНЗ та виявленні прогалин у розвитку будь-якого компоненту ІКК результати діагностування можуть слугувати орієнтирами або цільовими показниками, відповідно до яких вимірюється поточний стан розвитку ІКК слухачів (курсантів).

2. Викладачі ІМ ВBНЗ мають вміти описувати, інтерпретувати належним чином результати діагностичних досліджень, робити діагностичний висновок для удосконалення педагогічної практики та підвищення ефективності освітнього процесу загалом.

3. Спираючись на сутнісні характеристики ІКК офіцерів Збройних Сил України, треба зазначити, що процес педагогічного діагностування має охоплювати розроблення діагностичного інструментарію та здійснюватися у таких напрямах, як: вивчення індивідуальних особливостей до опанування 
іноземної мови; розвиток комплексу професійних цінностей і мотивів; рівень сформованості мовної компетентності (використання граматичних форм та конструкцій, знання лексики тощо);рівень сформованості мовленнєвої компетентності (читання, аудіювання, говоріння, письмо);рівень сформованості соціолінгвістичних знань, що сприяють їхній ефективній військово-професійній діяльності в офіційних i неформальних ситуаціях; готовність офіцерів виконувати професійні завдання в іншомовному середовищі самостійно та мобільно; здатність до рефлексії, до самоаналізу й самоспостереженню за своїм прогресом, критичне оцінювання власних здібностей і знань з іноземної мови.

Перспективами подальших досліджень вбачаємо дослідження структури діагностичної компетентності викладачів іноземних мов вищих військових навчальних закладів, розроблення критеріїв i норм оцінювання рівнів сформованості іншомовної комунікативної офіцерів Збройних Сил України.

\section{ЛІТЕРАТУРА}

1. Бандура, Ю. Б. (2014). Розвиток професійної компетентності викладачів іноземних мов вищих військових навчальних закладів у післядипломній освіті : автореф. дис. ... канд. пед. наук : 13.00.04. Київ,20.Взято з URL: http://er.nau.edu.ua/handle/NAU/20704.

2. Вітченко, А. О., Осьодло В. І. (2017).Педагогіка вищої військової школи : підручник Київ : НУОУ ім. Івана Черняховського,504.

3. Вітченко, А. О., Рибчук, О. О.(2015). Діагностика сформованості фахової компетентності майбутніх викладачів ВВНЗ як педагогічна проблема. Збірник наукових праџь «Військова освіта» НУОУ. Київ. № 1 (31), 50-63.

4. Гац, Г. О. (2010).Методика формування діагностичної компетентності майбутніх учителів фізичної культури. Педагогіка, психологія та медикобіологічні проблеми фізичного виховання спорту. № 3, $i$ 18-20. Взято 3 URL: https://www.sportpedagogy.org.ua/html/journal/2010-03/10ggoptt.pdf

5. Головань, М. С. (2012).Компетентнісний підхід у процесі професійної підготовки фахівців у вищих навчальних закладах. Наукова діяльність як шлях формування професійних компетентностей майбутнього фахівия: зб. Матеріалів III міжвузівської наук.-практ. конф. Суми : Вид-во СумДПУ імені А. С. Макаренка, 21-23.

6. Діденко, О.В. (2014).Особливості впровадження компетентнісного підходу у професійну підготовку майбутніх офіцерів у ВНЗ. Вісник Національної академії Державної прикордонної служби України. Серія : педагогічні науки : електрон. наук. фахов. вид. Хмельницький. Випуск 3. Взято з URL: http://nbuv.gov.ua/UJRN/Vnadps_2014_3_6.

7 Дорофеева, О. И. (2013). Формирование диагностической компетентности педагогов в процессе дополнительного профессионального образования : монография. Вологда : издат. центр ВИРО, 164.

8. Драч, I.I. (2008).Компетентнісний підхід як засіб модернізації змісту вищої освіти. Проблеми освіти. № 57, 44-47.

9. Дубасенюк, О.А. (2011).Професійна педагогічна освіта: компетентнісний підхід : монографія / за ред. О. А. Дубасенюк. Житомир : Вид-во ЖДУ імені І. Франка, 412.

103язюн, I. А. (2005).Філософія поступу і прогнозу освітньої системи. Педагогічна майстерність: проблеми, пошуки, перспективи: монографія.К.; Глухів: РВВ ГДПУ, 10-18.

11. Мартиненко, С. М. (2012). Формування діагностичних компетенцій у майбутніх учителів початкової школи. Педагогіка вищої та середньої школи.Вип. 36,26-31. Взято 3 URL: http://www.irbis-nbuv.gov.ua/cgibin/irbis_nbuv/cgiirbis_64.exe?C21COM=2\&I21DBN= UJRN\&P21DBN=UJRN\&IMAGE_FILE_DOWNLOAD=1\&Image_file_name=PDF/PVSSh_2012 _36_6.pdf. 
12. Пометун, О. І. (2004).Теорія та практика послідовної реалізації компетентнісного підходу в досвіді зарубіжних країн. Компетентнісний підхід у сучасній освіті: світовий досвід та украӥнські перспективи. Київ : К.І.С., 7-25.

13. Про основні засади мовної підготовки особового складу у системі Міністерства оборони України : наказ Міністерства оборони України від 08.08.2019. URL: Взято з: https://nuou.org.ua/assets/documents/osn-zas-mp.pdf.

14. Равен,Дж. (2002).Компетентность в современном обществе: выявление, развитие и реализация. Москва : Когито-Центр, 396.

15. Ягупов, В. В., Свистун, В. І. (2007).Компетентнісний підхід до підготовки фахівців у системі вищої освіти. Наукові записки Національного університету «Києво-Могилянська академія». Київ. Том 71 : Педагогічні, психологічні науки та соціальна робота, 3-8.

16. Aufschnaiter, C. G. Dübbelde, M. Ennemoser, J. Mayer, J. Stiensmeier-Pelster, R. Straesser, A. Wolgastd (2010). Establishingand Diagnosing Prospective Teachers' Diagnostic Competenc. Posterpresentedat NARST.

17. Barth, C., Henninger, M. (2012). Fosteringthe Diagnostic Competence of Teachers with Multimedia Training - A Promising Approach? Inbook: Interactive Multimedia., 48-66.

18. Chauvigné, C., Coulet J. C. (2010). «L'approche par compétences: un nouveau paradigme pour la pédagogie universitaire ? ». Revue française de pédagogie [Enligne], Взято 3 URL : http://journals.openedition.org/rfp/2169 ; DOI : https://doi.org/10.4000/rfp.2169.

19. Klug, J., Bruder,S., Kelava, A.,Spiel, C.,Schmitz,B., (2013). UniversitätWien, Vienna, Austria. Diagnostic competence of teachers: A process model that accounts for diagnosing learning behavi or tested bymeans of a casescenario. Teachingand Teacher Education 30. 38-46.

20.Klug, J., Gerich, M., Schmitz, B. (2016). Which variable spredict teachers diagnostic competence when diagnosing students' learning behavior at differents tages of a teacher'scareer? Journal Teachers and Teaching, theory andpractice 22 (4).

21. Monchatre, S. (2008). L'approche par competences, technologie de rationalisation pedagogique. Le cas de la formation professionnelle au Quebec,. Net.Doc, 36, 1-55.

22. Yahupov, V., Zastelo, O., Svystun, V., Korchynska, N., Chorna, O., Krykun, V. (2020).Development of Foreign V. Language Teachers' Diagnostic Competence in the System of Military Education. TEM Journal. 9(3), 1213-1220, ISSN 2217-8309, DOI: 10.18421/TEM93-49.

23. Vogt, F., Rogalla, M. (2009). DevelopingAdaptiveTeachingCompetencythroughcoaching. TeachingandTeacherEducation. 25(8), 1051-1060.

\section{REFERENCES}

1. Bandura, Yu. B. (2014). Rozvytok profesiinoi kompetentnosti vykladachiv inozemnykh mov vyshchykh viiskovykh navchalnykh zakladiv u pisliadyplomnii osviti : avtoref. dys. ... kand. ped. nauk : 13.00.04. Kyiv,20.Vziato z URL: http://er.nau.edu.ua/handle/NAU/20704.

2. Vitchenko, A. O., Osodlo V. I. (2017).Pedahohika vyshchoi viiskovoi shkoly : pidruchnyk Kyiv : NUOU im. Ivana Cherniakhovskoho,504.

3. Vitchenko, A. O., Rybchuk, O. O.(2015). Diahnostyka sformovanosti fakhovoi kompetentnosti maibutnikh vykladachiv VVNZ yak pedahohichna problema. Zbirnyk naukovykh prats «Viiskova osvita» NUOU. Kyiv. № 1 (31), 50-63.

4. Hats, H. O. (2010).Metodyka formuvannia diahnostychnoi kompetentnosti maibutnikh uchyteliv fizychnoi kultury. Pedahohika, psykholohiia ta medykobiolohichni problemy fizychnoho vykhovannia i sportu. № 3, 18-20. Vziato $\mathrm{z}$ URL: https://www.sportpedagogy.org.ua/html/journal/2010-03/10ggoptt.pdf

5. Holovan, M. S. (2012).Kompetentnisnyi pidkhid u protsesi profesiinoi pidhotovky fakhivtsiv u vyshchykh navchalnykh zakladakh. Naukova diialnist yak shliakh formuvannia profesiinykh kompetentnostei maibutnoho fakhivtsia: zb. Materialiv III mizhvuzivskoi nauk.-prakt. konf. Sumy : Vyd-vo SumDPU imeni A. S. Makarenka, 21-23.

6. Didenko, O. V. (2014).Osoblyvosti vprovadzhennia kompetentnisnoho pidkhodu u profesiinu pidhotovku maibutnikh ofitseriv u VNZ. Visnyk Natsionalnoi akademii Derzhavnoi 
prykordonnoi sluzhby Ukrainy. Seriia : pedahohichni nauky : elektron. nauk. fakhov. vyd. Khmelnytskyi. Vypusk 3. Vziato z URL: http://nbuv.gov.ua/UJRN/ Vnadps_2014_3_6.

7. Dorofeeva, O. Y. (2013). Formyrovanye dyahnostycheskoi kompetentnosty pedahohov v protsesse dopolnytelnoho professyonalnoho obrazovanyia : monohrafyia. Volohda : yzdat. tsentr VYRO, 164.

8. Drach, I.I. (2008).Kompetentnisnyi pidkhid yak zasib modernizatsii zmistu vyshchoi osvity. Problemy osvity. № 57, 44-47.

9. Dubaseniuk, O. A. (2011).Profesiina pedahohichna osvita: kompetentnisnyi pidkhid : monohrafiia / za red. O. A. Dubaseniuk. Zhytomyr : Vyd-vo ZhDU imeni I. Franka, 412.

10Ziaziun, I. A. (2005).Filosofiia postupu i prohnozu osvitnoi systemy. Pedahohichna maisternist: problemy, poshuky, perspektyvy: monohrafiia.K.; Hlukhiv: RVV HDPU, 10-18.

11. Martynenko, S. M. (2012). Formuvannia diahnostychnykh kompetentsii u maibutnikh uchyteliv pochatkovoi shkoly. Pedahohika vyshchoi ta serednoi shkoly.Vyp. 36,26-31. Vziato z URL: http://www.irbis-nbuv.gov.ua/cgibin/irbis_nbuv/cgiirbis_64.exe?C21COM=2\&I21DBN= UJRN\&P21DBN=UJRN\&IMAGE_FILE_DOWNLOAD=1\&Image_file_name=PDF/PVSSh_2012 _36_6.pdf.

12. Pometun, O. I. (2004).Teoriia ta praktyka poslidovnoi realizatsii kompetentnisnoho pidkhodu v dosvidi zarubizhnykh krain. Kompetentnisnyi pidkhid u suchasnii osviti: svitovyi dosvid ta ukrainski perspektyvy. Kyiv : K.I.S., 7-25.

13. Pro osnovni zasady movnoi pidhotovky osobovoho skladu u systemi Ministerstva oborony Ukrainy : nakaz Ministerstva oborony Ukrainy vid 08.08.2019. URL: Vziato z: https://nuou.org.ua/assets/documents/osn-zas-mp.pdf.

14. Raven,Dzh. (2002).Kompetentnost v sovremennomobshchestve: vыiavlenye, razvytye у realyzatsyia. Moskva : Kohyto-Tsentr, 396.

15. Yahupov, V. V., Svystun, V. I. (2007).Kompetentnisnyi pidkhid do pidhotovky fakhivtsiv u systemi vyshchoi osvity. Naukovi zapysky Natsionalnoho universytetu «Kyievo-Mohylianska akademiia». Kyiv. Tom 71 : Pedahohichni, psykholohichni nauky ta sotsialna robota, 3-8.

16. Aufschnaiter, C. G. Dübbelde, M. Ennemoser, J. Mayer, J. Stiensmeier-Pelster, R. Straesser, A. Wolgastd (2010). Establishingand Diagnosing Prospective Teachers Diagnostic Competenc. Posterpresentedat NARST.

17. Barth, C., Henninger, M. (2012). Fosteringthe Diagnostic Competence of Teachers with Multimedia Training - A Promising Approach? Inbook: Interactive Multimedia., 48-66.

18. . Chauvigné, C., Coulet J. C. (2010). «L'approche par compétences: un nouveau paradigme pour la pédagogie universitaire ?». Revue française de pédagogie [Enligne], Взято 3 URL : http://journals.openedition.org/rfp/2169 ; DOI : https://doi.org/10.4000/rfp.2169.

19. Klug, J., Bruder,S., Kelava, A.,Spiel, C.,Schmitz,B., (2013). UniversitätWien, Vienna, Austria. Diagnostic competence of teachers: A process model that accounts for diagnosing learning behavi or tested bymeans of a casescenario. Teachingand Teacher Education 30. 38-46.

20.Klug, J., Gerich, M., Schmitz, B. (2016). Which variable spredict teachers diagnostic competence when diagnosing students learning behavior at different stages of a teachers career? Journal Teachers and Teaching, theory andpractice 22 (4).

21. Monchatre, S. (2008). Lapproche par competences, technologie de rationalisation pedagogique. Le cas de la formation professionnelle au Quebec,. Net.Doc, 36, 1-55.

22.Yahupov, V., Zastelo, O., Svystun, V., Korchynska, N., Chorna, O., Krykun, V. (2020).Development of Foreign V. Language Teachers Diagnostic Competence in the System of Military Education. TEM Journal. 9(3), 1213-1220, ISSN 2217-8309, DOI: 10.18421/TEM93-49.

23. Vogt, F., Rogalla, M. (2009). DevelopingAdaptiveTeachingCompetencythroughcoaching. TeachingandTeacherEducation. 25(8), 1051-1060. 
РЕЗЮМЕ

ЮлияГрищук, адъюнкт, Национальный университет обороны Украины имени Ивана Черняховского, г. Киев

\section{Проблема развития диагностической компетентности преподавателей высшей военной школы впедагогической теории и практике}

В статье осуществлен анализ состояния исследования теории и практики развития диагностической компетентности преподавателей иностранных языков высших военных учебных заведений и изучены современные научные взгляды на эту проблему, проанализировано и дифференцировано сущиность ключевых понятий компетентностного подхода: «компетентность» $u$ «профессиональная компетентность преподавателя выстего военного учебного заведения».

Ключевые слова: диагностическая компетентность преподавателя вуза; компетентностный подход; компетентность; профессиональная компетентность преподавателя вуза; иноязычная коммуникативная компетентность

\section{SUMMARY}

Yuliia Hryshchuk, PhDMilitary Student, National Defence University of Ukraine named after Ivan Cherniakhovskyi

\section{The problem of developing the diagnostic competence of higher military educational institutions teachers in pedagogical theory and practice}

Introduction.The article analyzes the state of research of the theory and practice of the development of diagnostic competence of teachers of foreign languages of higher military educational institutions and studies modern scientific views on this problem, analyzes and differentiates the essence of the following key concepts of the competence-based approach: «competence» and "professional competence of a teacher of a higher military educational institution».

The purpose is theoretical analysis of the problem of development of diagnostic competence of foreign language teachers of higher military educational institutions

Methods. To achieve the goal and solve the tasks, it was used a system of the following theoretical research methods: analysis, synthesis, generalization and systematization.

Results. It is substantiated that intelligent adaptive systems have different capabilities and features in the context of adaptation to student changes, providing feedback to the teacher and student and intellectual support based on the needs of the subject of educational process.

Originality. In accordance with the main provisions of the language policy of the Armed Forces of Ukraine, a modern foreign languages teacher of higher military institution is assigned to fulfilla number of tasks, including the formation and development of foreign language communicative competence of students (cadets) using modern methodology. It provides the ability to choose and develop the necessary diagnostic tools, to describe, properly interpret the results of diagnostic research, to make a diagnostic conclusion in order to improve pedagogical practice and increase the efficiency of the educational process as a whole.

Conclusion. The problem of developing the diagnostic competence of foreign languages teacher of a higher military institution is topical.Nowadays in modern science there is a lack of thorough, modern research related to this issue. Providing the appropriate level of development of diagnostic competence of foreign languages teacherof a higher military institution and identifying 
gaps in the development of any component offoreign language communicative competence of students (cadets), the results of diagnosis can serve as guidelines or targets, according to which the current state of foreign language communicative competence of students (cadets)development is measured.

Key words: diagnostic competence of a university teacher; competence-based approach; competence; professional competence of a university teacher; foreign language communicative competence. 